\title{
コールドスプレー法における固相粒子の付着メカニズム
}

\author{
小 川 和 洋 $^{\mathrm{a}}$
}

a 東北大学大学院工学研究科 附属エネルギー安全科学国際研究センター

（９ 980-8579 宮城県仙台市青葉区荒巻字青葉 6-6-01）

\section{Mechanisms of Solid Particle Deposition in Cold Spray}

\section{Kazuhiro OGAWA a}

${ }^{a}$ Fracture and Reliability Research Institute, Graduate School of Engineering, Tohoku University (6-6-01, Aoba, Aramaki, Aoba-ku, Sendai-shi, Miyagi 980-8579)

Keywords : Cold Spray, Solid Particle, Deposition Mechanism, Metallic Coating, Ceramic Coating

\section{1.はじめに}

コールドスプレー(Cold Spray：CS) 法は, 1980 年代に Alkhimov, Papyrin らによって考案された比較的新しい手法 であり ${ }^{1)}$, Cold Gas Dynamic Spray や Kinetic Spray とも呼ば れる。CS 法は, 空気, 窒素 $\left(\mathrm{N}_{2}\right)$ またはへリウム $(\mathrm{He})$ などの 圧縮気体により, 数十 $\mu \mathrm{m}$ オーダーの金属微粒子を亜音速か ら超音速レベルにまで加速し, 固相状態のまま基材に衝突さ せることにより数百 $\mu \mathrm{m}$ から数十 $\mathrm{mm}$ の厚い皮膜を形成させ ることが可能な技術である。CS 装置の機器構成は比較的シ ンプルで, ガスを体積膨張させ高速ガス流を作るヒーター, 粒子を送る粉末供給装置, および粒子をガス流に乗せて加速 させるためのノズルである。現在 CS 法は，プラズマなどに よって金属やセラミックス微粒子を溶融させ基材に衝突させ ることにより皮膜を形成させる溶射 (TS：Thermal Spray)の 一種に分類されている。しかしながら CS 法は, 粒子を溶融 させることなく固相状態のまま成膜する点で従来の溶射法と 決定的に異なる。そのため, 大気中で緻密な皮膜が施工可能, 酸化, 熱影響, および熱応力を抑制, 厚膜 ( $\mathrm{cm}$ オーダー)の 施工が可能, 圧縮残留応力を有する皮膜が形成, 施工速度が 極めて速いなど様々な利点を有する ${ }^{2) 7)}$ 。さらに, 近年では 一部のセラミックス材料に関しても成膜が可能となっており， CS 法の可能性が拡がっている。

しかし，粒子の付着メカニズムに関しては，未だ統一した 見解がなく, 多くの研究者らが, 様々な付着メカニズムを提 案している。例えば, Y. Xiong $ら^{8)}$ は $\mathrm{Al}$ 基材上への $\mathrm{Al}$ 粒子 付着の場合, 粒子が基材へ衝突する際, 断熱昇温と急速冷却 により動的なアモルファス化と再結晶が起こり, 数 $\mathrm{nm}$ のア モルファス層ができることで接合が起こっていると述べてい る。X.J. Ning ら ${ }^{9)}$ は, Al-Sn 合金を SUS304 上へ付着させた 場合, 粒子の衝突時にSn が溶融し, これが接着剂的な作用 をすることで付着していると述べている。また， M. Grujicic $ら^{10)}$ は, 粒子衝突時に界面近傍で大きなせん断応力が作用し,
粒子が基材へ巻き込むように変形することによる機械的なイ ンターロック効果が付着に効いていると述べている。このよ うに付着メカニズムは, 界面近傍でのアモルファス化・再結 晶化による結合, 粒子表面の極表層部分が溶融することによ る接合，あるいはせん断変形による機械的な接合など，様々 な提案がなされているものの, 詳細なメカニズムは未解明の ままである。付着メカニズムが未解明であることは, CS 法 を適用したアプリケーション拡大の障害となっており, 早急 に付着メカニズムを明らかにし, 安全・安心な CS 皮膜・CS 補修を実現すべきである。本稿では，CS 法による固相粒子 の付着メカニズムに関し, 著者らが検討した低圧型 CS によ る $\mathrm{Al}$ 基材上への $\mathrm{Al}$ 粒子の付着メカニズム検討例を紹介する。 また，低圧型 CS を利用したセラミックス材料の付着条件に 関しても説明し，金属粒子が付着する場合との違いについて も解説する。

\section{2. 低圧および高圧コールドスプレー}

CS 法は, その作動ガス圧力および作動ガス温度から低圧 型と高圧型に大別される。現在高圧型と呼ばれているものは, 作動ガス圧力が $2 \sim 5 \mathrm{MPa}$ 程度であり, 作動ガス温度は最 大で $1000{ }^{\circ} \mathrm{C}^{11)}$ となっている。高温高圧による粒子速度の増 加や粒子温度の上昇により, 高融点金属材料も高効率で成膜 することを可能にしている。しかしながら，高温高圧を成し 遂げるために，装置が比較的大規模になってしまう。

一方, 低圧型 CS は, 作動ガス圧力が $1 \mathrm{MPa}$ 以下であり, また作動ガス温度も最大で $400 \sim 500{ }^{\circ} \mathrm{C}$ 程度と高圧型に比べ 低い。そのため高温化による気体の体積膨張が稼げず，粒子 速度が高圧型に比べ遅い。そのため, 高融点金属材料は成膜 することが困難であり, 純 $\mathrm{Al}$ や純 $\mathrm{Cu}$ といった比較的軟ら かい金属材料の成膜が可能となっている。通常, 低圧型 CS 装置の作動ガス圧力は $0.5 \mathrm{MPa}$ 以下であり, 成膜効率は高圧 型に比べ顕著に劣る。しかしながら, 装置が非常にコンパク トであることや作動ガスに圧縮空気を利用可能といった利点 
も有する。このため, 現場でのオンサイト補修の可能性も高 い。また，セラミックス材料に関しては，後述するように， 高圧型 CS では粒子速度が速すぎることにより基材のエロー ジョンが発生してしまうため粒子が付着せず，低圧型の方が 付着しやすいといったケースもある。

高圧および低圧型 CS は一長一短であり，用途や材料に よって使い分けられるべきである。著者らは，低圧型，高圧 型両 CS 装置による成膜条件の最適化および成膜メカニズム の検討を行っているが, 本稿においては比較的メカニズムが 理解しやすい低圧型 CS における軟質材料であるアルミニウ ム材料の成膜メカニズムを紹介する。また，近年低圧型 CS 施工により成膜の可能性が見えてきたセラミックス材料の成 膜条件の関し，金属材料成膜条件との違いを紹介する。

\section{3. 低圧型 CS によるアルミニウム材料の成膜メカニ ズム}

低圧型 CS は，粒子速度が $300 \mathrm{~m} / \mathrm{sec}$ 前後であり ${ }^{12)}$, 高圧 型のそれに比べ低いことから, 現在, アルミニウムや銅など の軟らかい金属の付着が主である。ここでは，著者らが実施 した低圧型 CS によるアルミニウム材の成膜に関し，検討例 を述べる。

図 1 に低圧型 CS により成膜した純アルミニウム $(\mathrm{Al})$ 基材 上への純 $\mathrm{Al}$ 粉末 (平均粒径 : $26.5 \mu \mathrm{m}$ ) の走査型電子顕微鏡 (SEM : Scanning Electron Microscope) 断面観察例を示す。こ のときのスプレー条件は, 作動ガスに圧縮空気, ガス圧力 $0.5 \mathrm{MPa}$ ，ノズル出口ガス温度 $320{ }^{\circ} \mathrm{C}$ ，ノズル / 基材間距離 $10 \mathrm{~mm}$ ，およびトラバース速度 $0.5 \mathrm{~m} / \mathrm{sec}$ とした。図からわ かるように, $\mathrm{Al}$ 皮膜は, 緻密で, 気孔も少なく, さらに基 材／皮膜の界面が判別できないほど良好に付着している。し かし，低圧型 CS による成膜は，成膜効率が低く，数\%の レベルである。一方，高圧型 CS で成膜した場合は，成膜効 率は高く，80〜 90\%程度となる。図 2 に低圧・高圧型 CS

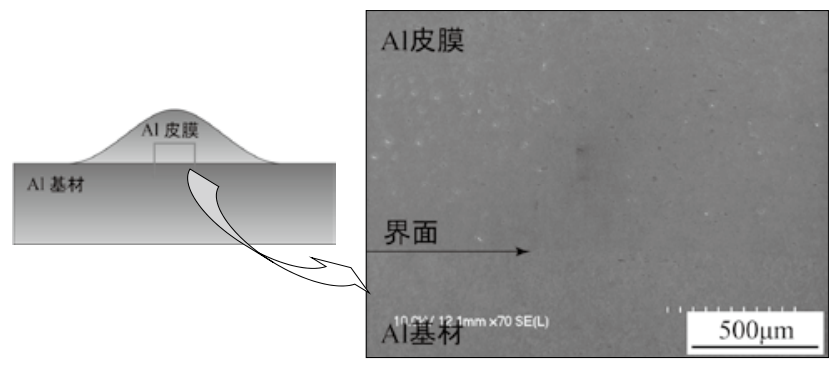

図 1 低圧型 $\mathrm{CS}$ により成膜した純 $\mathrm{Al}$ 皮膜の断面 SEM 観察例
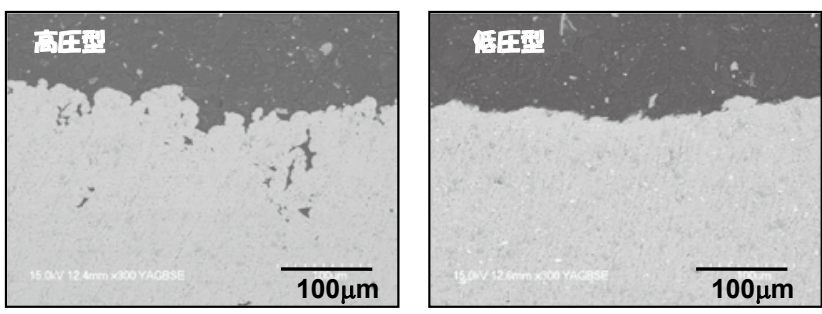

図 2 高圧型および低圧型 $\mathrm{CS}$ により成膜した純 $\mathrm{Al}$ 皮膜の比較
で施工したアルミニウム同材の成膜結果を示す。成膜条件に よっても皮膜の様相は変化するが，本結果においては，低圧 型 CS による成膜は高圧型に比べ，表面の気孔率が極めて低 いことがわかる。これは，成膜効率が高圧型に比べ顕著に低 いため, 多くの粒子は付着せず表面に衝突し跳ね返るが，こ の付着しない粒子が付着した粒子に衝突し，粒子を潰す(塑 性変形させる)ことによって, 緻密に成膜されたものと考え られる。高圧型の場合, 粒子の速度が速く, 付着に十分な運 動エネルギーが得られるため, 成膜効率は顕著に高くなる。 しかし，付着した粒子表面を潰す役割を果たす付着しない粒 子が少ないために, 表面近傍のみ気孔率が高くなっているも のと考えられる。

低圧型 CS における成膜効率の検討結果を図 3 に示す。こ こでは，膜厚を変化させた場合の成膜効率を検討しており, 膜厚が $200 \mu \mathrm{m}$ までは膜厚が厚くなるに従い成膜効率が向上 し，その後はほぼ一定となることが確認され，このときの成 膜効率は $7 \%$ 程度であった。成膜効率測定方法は, スプレー 前後の粒子および基材の質量を測定し，さらに配管内等に残 存した粒子の質量 $M$ を考慮し，次式から求めている。

$$
\mathrm{D}=\frac{\text { スプレー後の基材質量ースプレー前の基材質量 }}{\text { スプレー前の粒子材質量ースプレー後残存した粒子質量 }-\mathrm{M}} \times 100(\%)(1)
$$

この評価法は，ノズル内や配管内に残存する粒子をエアで 押し出し, 回収した粒子の質量を求めているが，完全に全て の粒子を回収することは難しく誤差が生じる可能性があり, 得られた結果は必ずしも正確な值ではない。しかし，この点 を差し引いても低圧型 CS による純 $\mathrm{Al}$ の成膜効率は顕著に 低くなることがわかる。また，膜厚が $200 \mu \mathrm{m}$ までは膜厚が 厚くなるに従い成膜効率が向上していることから, 後続粒子 によって皮膜が潰され，緻密化していく過程で成膜が困難に なっていることや, 成膜の第一段階である基材 / 粒子間の付 着と基材上に付着した粒子上へさらに粒子が付着する場合 (粒子/粒子)ではそれらの成膜メカニズムが異なり基材/粒 子間の付着がより困難であることが考えられる。このことか ら，基材への粒子の付着において “遅れ時間”（粒子の衝突 がある程度起こった後に付着が生じる)が存在している可能 性が示唆された。

この遅れ時間が基材上への粒子付着に関し重要な役割を担

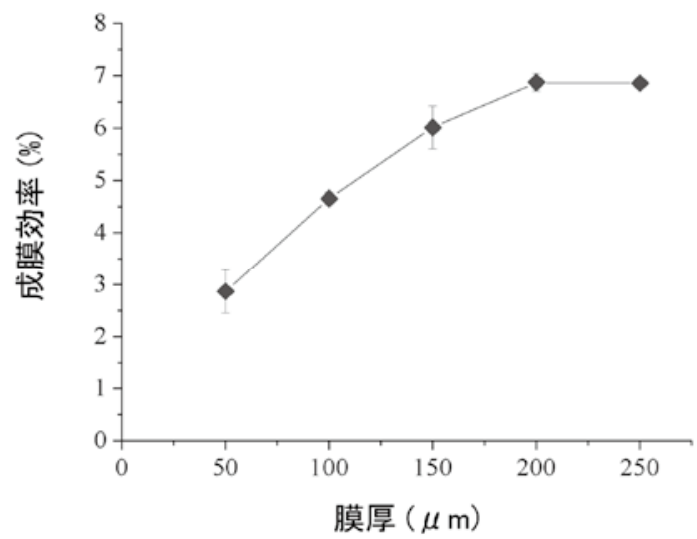

図 3 低圧型 CS による成膜効率 
うことが考えられるため，遅れ時間に関し検討を行った。

図 4 に遅れ時間評価実験における概略図を示す。

スプレー開始から粒子が付着し始めるまでの時間を直接評 価することは非常に困難であるため，粒子の供給量を減らし， 基材を $0.5 \mathrm{~m} / \mathrm{sec}$ の高速度でトラバース (ガンの移動)させ, 粒子を分散させて衝突させた。トラバース回数の異なる試料 を作製し, 何回目のトラバースで付着開始するかを確認し, 遅れ時間の存在を確認した。評価は，1回のスプレーにおい て粒子が付着する幅が $5 \mathrm{~mm}$ 程度であることから, 図 4 に示 したスプレー領域における $5 \mathrm{~mm}^{2}$ 内の付着粒子数を SEM に より観察し, 各トラバース回数における付着粒子数を評価し た。評価においては, 粒子あるいはコンタミネーションの判 別が困難であるため, 粒径が $5 \mu \mathrm{m}$ 以下のものについては除

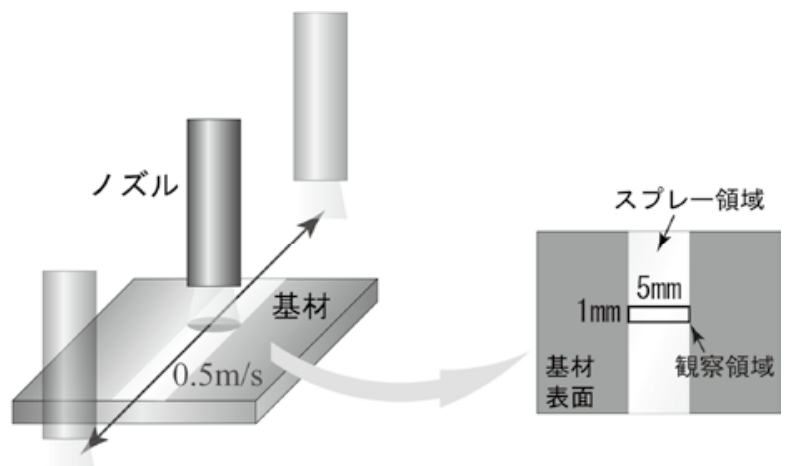

図 4 遅れ時間評価試験の概略図

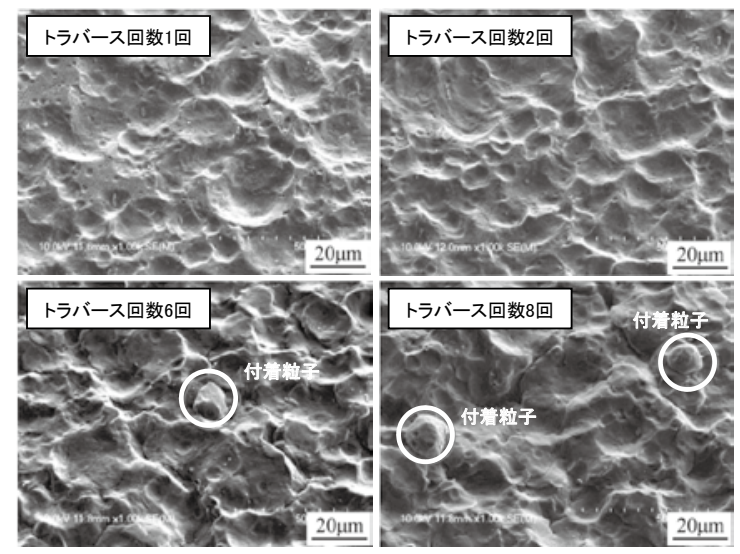

a)基材表面に付着したAI粒子の外観

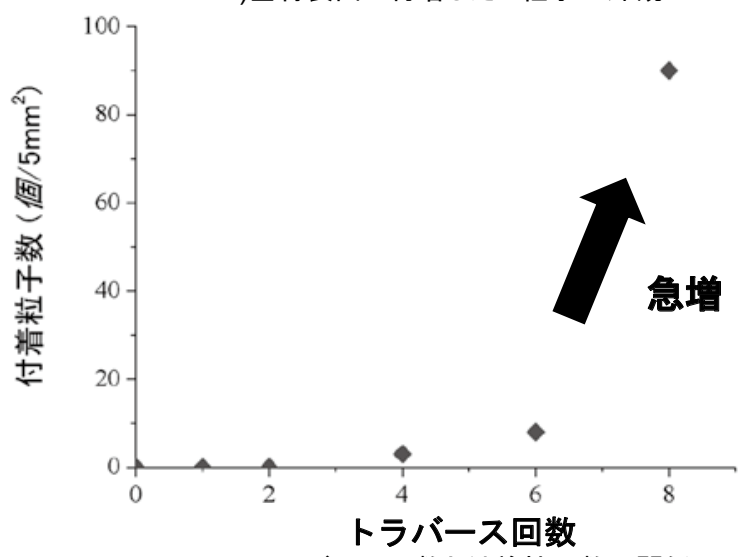

b)トラバース回数と付着粒子数の関係

図 5 各トラバース回数における基材表面粒子付着状況
外している。

図 5 に各トラバース回数における基材表面 SEM 像および トラバース回数による付着粒子数変化を示す。

トラバース回数 1 回および 2 回においては粒子の付着は全 く確認されなかったが, 6 回から 8 回にかけては付着粒子数 が顕著に増加していることが確認された。このことから，低 圧型 $\mathrm{CS}$ における純 $\mathrm{Al}$ 基材上への純 $\mathrm{Al}$ 粒子の成膜時におい ては，粒子が付着し始めるまでの遅れ時間が存在しているこ とが明らかとなった。遅れ時間の存在は，粒子が繰り返し基 材に衝突することによって基材表面硬さ，粗さあるいは活性 度などの状態が変化し, 粒子が付着しやすくなったことを意 味している。

上述のように，粒子は 1 回の衝突では付着せず繰り返し基 材に衝突することにより付着に至る。この際，粒子の衝突回 数が増加するにつれ，基材表面粗さが大きく変化している様 子が確認された。またこのことは，基材表面組織の変化，粒 子衝突による基材表面の加工硬化，および粒子の衝突による 基材表面の活性化(新生面の露出)などが考えられる。これま での検討により，これらの中でも最も粒子の付着に影響を及 ぼす因子は，粒子が基材へあるいは粒子が粒子へ衝突した際 に新生面が露出することによる粒子および基材表面の活性化 であることがわかってきている。大気中では $\mathrm{Al}$ 表面に数 $\mathrm{nm}$ の自然酸化膜が生成しており，これが破壊され新生面が露出 することにより活性化し, 粒子が付着し始めることが推測さ

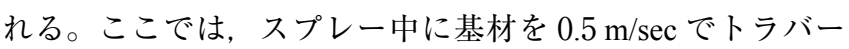
スさせたときのインターバル(最初のトラバースと次のトラ バースの間の待ち時間)を変えることにより，基材表面の活 性度合いを変化させた。基材表面の活性化が粒子の繰り返し 衝突による自然酸化膜の破壊による新生面の生成であるなら ば，インターバルが長くなるほど，生成した新生面は再度酸 化し基材表面の活性度合いは低下する。

各インターバルの条件にて基材表面にスプレーしたときの パス回数に対する付着粒子数の変化を図 6 に示す。

$1800 \mathrm{sec}$ おび $3600 \mathrm{sec} に$ 関しては，1から 10 回までの トラバースでは粒子の付着が認められず，12 トラバース後 の付着粒子数のみの評価となっている。インターバルが長く なるほど付着粒子数が減少し，1800 sec および $3600 \mathrm{sec} に お ~$ いて粒子はほとんど付着しないことが確認されている。また,

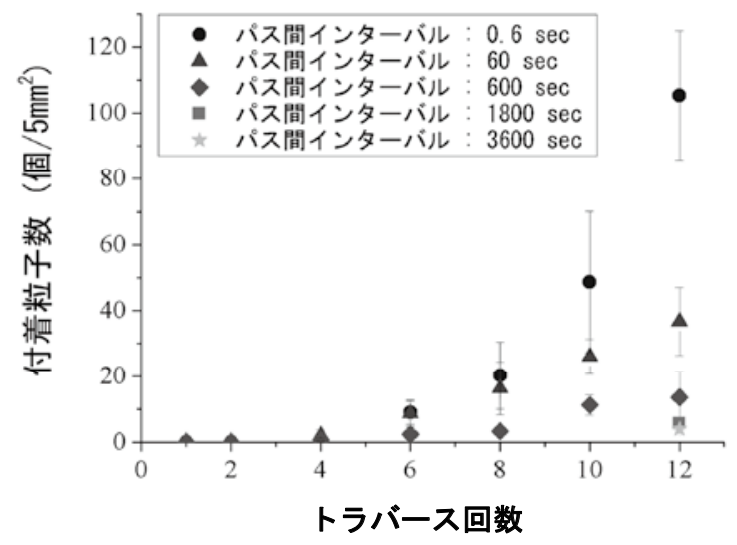

図 6 インターバル変化に伴う付着粒子数とトラバース回数の関係 
12 トラバース時におけるインターバルに対する付着粒子数 の変化を図 7 に示す。

この結果から，インターバルが $0.6 \mathrm{sec}$ から $60 \mathrm{sec}$ までの 間で付着粒子数が急激に減少し, その後 $1800 \mathrm{sec}$ までは徐々 に付着粒子数が減少していく傾向が認められた。以上から, 最初のトラバースで $\mathrm{Al}$ 基材上の自然酸化皮膜が除去され新 生面が露出するが，インターバルを長くすることで表面には 酸化物が再生・成長し，その酸化皮膜が厚くなるほど粒子は 付着しなくなることがわかった。すなわち, 酸化皮膜厚さが 粒子付着には極めて重要であることがわかる。また，前述し た遅れ時間の発生は, 粒子の衝突により自然酸化皮膜を除去 させ，新生面を露出させるまでの時間と考えられる。高圧型 CS の場合, 粒子速度が低圧型に比べ顕著に速くなるため, 自然酸化物の除去および新生面の露出が容易になり，付着効 率が高くなることが考えられる。低圧型においても基材表面 の自然酸化皮膜をいかに効率よく除去できるかを検討するこ とで付着効率を向上させることが可能になるものと考える。 以上をまとめると, 低圧型 CS は現段階では付着効率が低い ものの, 緻密で気孔の少ない皮膜を成膜することが可能であ り，さらに装置自体がコンパクトで，作動ガスに安価な圧縮 空気を使えることから, 現場でのオンサイト補修に大きく貢 献することが予測される。今後の課題としては, 他のプロセ スとの組み合わせなどにより，基材表面を如何に効率よく活 性化させられるかを検討し, 付着効率を向上させることが重 要である。

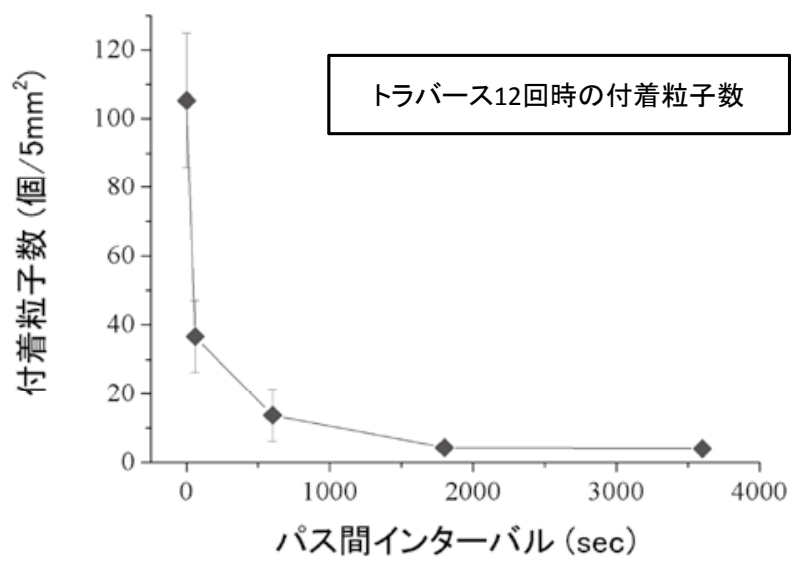

図 7 インターバル時間変化に伴う付着粒子数の変化

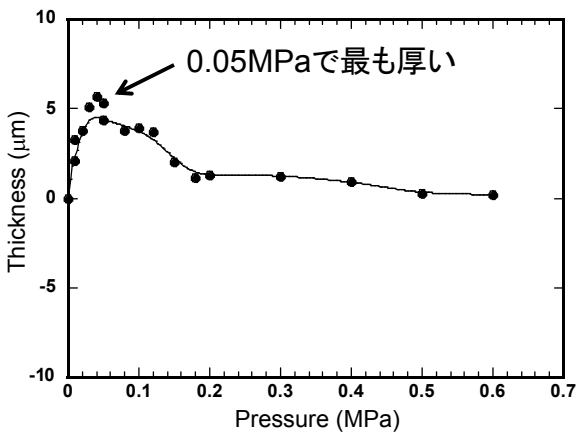

a) Inconel600基材

\section{4. セラミックス粒子付着のためのスプレー条件}

試験に用いたセラミックス材料は, チタン酸アルミニウム $\left(\mathrm{TiAl}_{2} \mathrm{O}_{5}\right)$ (オーセラ製)とし, 平均粒径 $2 \mu \mathrm{m}$ のものを用いた。 スプレーは，常温常圧で粒子をスプレーするパウダージェッ トデポジション(Power Jet Deposition：PJD) 法 ${ }^{13)}$ を用いた。 PJD 法の構造は, CS 法のそれとほぼ同様であるが, 加熱装 置が無く, 圧力も低圧型 CSよりも低い圧力に設定可能であ る。この PJDを用い, セラミックス粒子付着の最適化を目 的に，スプレー時の圧縮空気圧を変化させて試験を行った。 さらに，噴射回数を変化させ，より厚い皮膜を作製した。基 材には, $\mathrm{Ni}$ 基超合金 Inconel600，チタン酸アルミニウム焼結 材を用いた。成膜条件は, 圧力を $0.01 \sim 0.6 \mathrm{MPa}$ で変化させ, トラバース速度 $1 \mathrm{~mm} / \mathrm{sec}$, ノズルー基材間距離 $1 \mathrm{~mm}$ とし, 常温大気圧下で施工した。

異なる基材に対し，一回のスプレーで得られる膜厚と噴射 圧力の関係を評価した。膜厚の計測には表面粗さ形状測定機 （東京精密製，サーフコム 200A）を用い，噴射ラインと直角 に測定機の触針を走査し，ローパスフィルタを用いて粗さ成 分を取り除き，うねり成分を測定した。その時の最大高さを 膜厚とした。結果を図 8 に示す。Inconel600 および $\mathrm{TiAl}_{2} \mathrm{O}_{5}$ 両基材においても, 圧力 $0.05 \mathrm{MPa}$ の場合に最も粒子が付着 することがわかった。金属粒子付着の場合，このように低い 圧力で付着せず，金属粒子のそれとは全く異なる挙動を示す ことがわかった。粒子速度を高速度カメラを用い評価した結 果, $0.05 \mathrm{MPa}$ の圧力では, 粒子速度は約 $90 \mathrm{~m} / \mathrm{sec}$ となった。 金属粒子の場合, $300 \sim 1500 \mathrm{~m} / \mathrm{sec}$ の速度がないと付着しな いことから考え, セラミックス粒子の最適粒子速度は極めて 低いことがわかる。また, 圧力 $0.01 \mathrm{MPa}$ から $0.05 \mathrm{MPa}$ まで は圧力の増加に伴い粒子付着量も増加するものの, それ以降 は徐々に付着量が低下する傾向を示した。特に, $0.4 \mathrm{MPa}$ を 超えると粒子は付着せずに基材がエロージョンにより除去さ れる傾向を示した。これらの結果から, セラミックス粒子の 付着する条件範囲は極めて狭く, ピンポイントで付着条件を 見つけないといけないことがわかった。

また，繰り返しスプレーした場合，Inconel 600 基材では， 20 回の繰り返しにより, 約 $70 \mu \mathrm{m}$ 厚の成膜に成功している。 このことより, 今回用いた $2 \mu \mathrm{m}$ 径のセラミックス粒子は多 重に重なり合い，厚い皮膜の形成が可能であることがわかる。

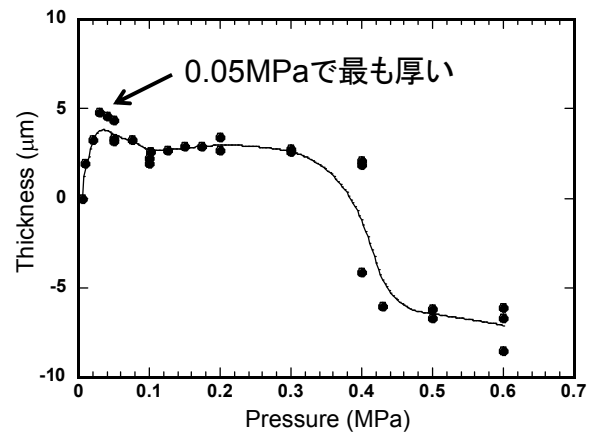

b) $\mathrm{TiAl}_{2} \mathrm{O}_{5}$ 基材

図 8 PJD 法により成膜した $\mathrm{TiAl}_{2} \mathrm{O}_{5}$ 粒子のガス圧力と成膜厚さの関倸 


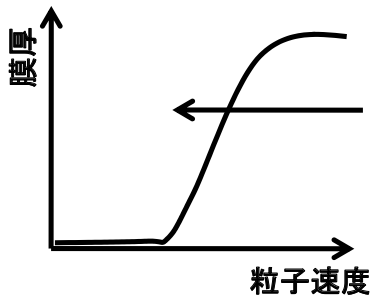

a) 金属粒子の場合

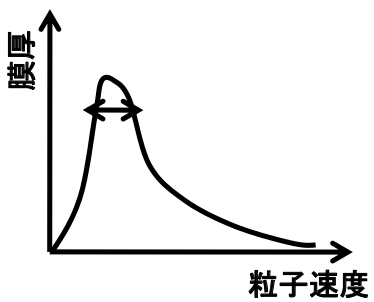

b) セラミックス粒子の場合
図 9 成膜挙動に関する金属粒子とセラミックス粒子の比較

金属粒子とセラミックス粒子を比較した場合, 図 9 に示す ように，金属粒子では臨界速度と呼ばれるある一定の速度を 超えることにより粒子が付着し始める現象が認められ, エ ロージョンが生じるまでの広範囲において粒子は付着する。

一方, セラミックス粒子の場合, 前述した結果のように, あ る適切な狭い速度条件でのみ付着し, 粒子速度が速くなると エロージョンが激しくなり，基材を削り落とす傾向を示す。 この結果から, 他のセラミックス粒子に関しても, ピンポイ ントの最適スプレー条件を見つけることが重要になると考え られるものの, CS 法を用いたセラミックス粒子成膜の可能 性が考えられる。

セラミックス粒子の付着メカニズムに関しては，金属粒子 のように「自然酸化皮膜が除去され新生面が露出する」とい う考え方が通用せず，金属とは異なる付着メカニズムが考え られる。

D.M. Chun $~^{14)}$ は, Nano-particle deposition system という手 法を用いたアルミナ基材上へのアルミナ粒子の成膜を行って おり，この場合，アルミナ粒子が基材へ衝突し，粒子がナノ オーダーに破壊し，微細になった粒子が連結することにより 成膜されると述べている。本稿で紹介した $\mathrm{TiAl}_{2} \mathrm{O}_{5}$ も同様の メカニズムで成膜されていることが考えられるが, 現時点で はその詳細は不明である。ただし，付着メカニズムは不明で あるものの, CS 法は金属粒子のみならず，七ラミックスへ の応用も可能な手法であり，今後の展開が期待される。

\section{5.まとめ}

低圧型コールドスプレーを用いた純 $\mathrm{Al}$ の成膜メカニズム および $\mathrm{TiAl}_{2} \mathrm{O}_{5}$ セラミック粒子の最適スプレー条件に関する 検討例を紹介した。 $\mathrm{Al}$ および $\mathrm{TiAl}_{2} \mathrm{O}_{5}$ は, 金属およびセラミッ クスと材料の種類は異なるものの, どちらも粒子を付着させ ることが可能である。しかし, 金属とセラミックスの粒子付 着メカニズムは，異なることが予測され，金属は自然酸化皮 膜が除去され新生面が露出することにより活性な面が露出す ることで付着し，セラミックスの場合は粒子がナノオーダー の粒径に破砕することで活性化するためと考えられる。今後, 金属ならびにセラミックスの詳細な成膜メカニズムを明らか にし，様々な分野への展開を図っていきたい。

(Received July 31, 2012)

\section{文献}

$1)$ A.P. Alkhimov, A.N. Papyrin, V.F. Kosarev, N.I. Nesterovich, M.M. Shushpanov; U.S. Patent No. 5, 302,414; April 12, 1994.

2 ）(財) 機械システム振興協会; 高速粒子衝突を利用した革新部材 創製に関する調查研究報告書, p. 9 （(財) 機械システム振興協会, 2005).

3 ) J. Karthikeyan ; INTERNATIONAL STATUS AND USA EFFORTS, ASB Industries Inc., p.1 (2004)

4) 榊 和彦; 溶射技術, 20,32 (2000).

5 ) 榊 和彦; 溶射技術, 21, 29 (2002).

6 ) J. Pattison, S. Celotto, R. Morgan, M. Bray, W. O'Neill ; International Journal of Machine Tools \& Manufacture, 47, 627 (2007).

7 ) S. Sampath, X.Y. Jiang, J. Matejicek, L. Prchlik, A. Kulkarni, A. Vaidya ; Materials Science and Engineering, A364, 216 (2004).

8 ) Y. Xiong, K. Kang, G. Bae, S. Yoon, C. Lee ; Applied Physics Letters, 92, 194101 (2008).

9 ) X.J. Ning, J.H. Jang, H.J. Kim, C.J. Li, C. Lee ; Surface \& Coatings Technology, 202, 1681 (2008).

10) M. Grujicic, J.R. Saylor, D.E. Beaslet, W.S. DeRosset, D. Helfritch ; Applid Surface Science, 219, 211 (2003).

11）プラズマ技研工業 (株) ; HP; http://www.plasma.co.jp/products/ coldspray.html (2012.7.31)

12) K. Ogawa, K. Ito, K. Ichimura, Y. Ichikawa, S. Ohno, N. Onda ; Journal of Thermal Spray Technology, 17, 728 (2008).

13）㕌川常元;トライボロジスト, 52, (1), 28 (2007).

14) D.M. Chun, S.H. Ahn ; Acta Materialia, 59, 2693 (2011). 